\title{
Nomophobia: An Individual's Growing Fear of Being without a Smartphone-A Systematic Literature Review
}

\author{
Antonio-Manuel Rodríguez-García ${ }^{\mathbb{D}}$, Antonio-José Moreno-Guerrero $\mathbb{D}$ \\ and Jesús López Belmonte *(D) \\ Department of Didactics and School Organization, University of Granada, 18071 Granada, Spain; \\ arodrigu@ugr.es (A.-M.R.-G.); ajmoreno@ugr.es (A.-J.M.-G.) \\ * Correspondence: jesuslopez@ugr.es
}

Received: 1 December 2019; Accepted: 12 January 2020; Published: 16 January 2020

check for updates

\begin{abstract}
This review examines the current literature focused on nomophobia (objectives, methodological design, main variables, sample details, and measurement methods) in the Scopus and Web of Science databases. To this end, we conducted a systematic literature review in accordance with the Preferred Reporting Items for Systematic Reviews (PRISMA) guidelines. The initial sample consisted of 142 articles, of which 42 met the inclusion criteria and were analyzed in detail. The findings show that the current research is in an exploratory phase, with a greater predominance of descriptive, nonexperimental, and cross-sectional studies that explore the prevalence of nomophobia mainly in adolescents and university students. The most widely used measurement instrument is the Nomophobia Questionnaire (NMP-Q) proposed by Yildrim and Correia. In addition, the research suggests that nomophobia negatively affects personality, self-esteem, anxiety, stress, academic performance, and other physical and mental health problems. We are therefore faced with a health problem, which negatively affects a person, causing psychological problems and physical and behavioral changes.
\end{abstract}

Keywords: nomophobia; smartphones; situational phobia; systematic review

\section{Introduction}

Today's smartphones present great opportunities and comforts for people; at the same time, they facilitate the accomplishment of tasks and have achieved generalized popularity in the present society [1] thanks to their communicative power and people's engagement with them [2]. The users of this technology even state that it has become an extension of their body, determining both their identity and their way of being [3].

It is indisputable that these devices have become an integral part of modern life [4] and have come to produce behavioral modifications in everyday habits and actions [5]. The advance of mobile technology, given its ubiquitous nature, has meant that the smartphone has become an indispensable resource in people's lives [6].

However, in recent years, the number of problems arising from the use of smartphones has increased considerably [7]. As a result, the number of investigations into the state of the matter has increased, characterizing this phenomenon as addictive, antisocial, and dangerous [8]. Smartphone addiction is so prevalent that it is already considered to be like any other addiction to harmful substances. Therefore, it is a public health problem [9], which is why, because of the excessive use of this device [10] and the dependence that this technology generates [11], a new pathology known as nomophobia is emerging [12] and being cataloged as a clinical disorder [13].

Nomophobia is seen as a type of contemporary phobia that emerged in the digital age [14-16], which is expanding after the integration of the smartphone into society [17]. This term has its origin in England and 
is the result of the conjunction "non-mobile" combined with "phobia", that is, fear, anxiety, and discomfort of not having a mobile device at a certain moment or not having access to a device when required [18-21]. In other words, nomophobia is the fear of feeling disconnected from the digital world [22].

According to [23] or [24], nomophobia is structured in four main dimensions and/or causes: (1) fear or nervousness for not being able to communicate with other people; (2) fear of not being able to connect; (3) fear of not being able to have immediate access to information; and (4) fear of the renunciation of the comfort provided by mobile devices.

Nomophobia promotes the development of mental disorders, personality disorders [25], as well as problems in people's self-esteem, loneliness, and happiness [26], especially in the younger population [27, 28]. All of this has a great impact on health, which has negative repercussions on other aspects of life such as study and work [29], by creating a strong dependence on mobile technology [30], affecting professional practice by provoking constant distractions [31]. In addition, it is influencing the relationships and interactions between individuals, producing a distance and isolation from the physical world [21].

This modern disorder increases, in turn, the fear of losing immediate access to any information and communication with others [32], which raises the indicators concerning depression, anxiety, anger, aggressiveness [33], stress, nervousness [34], emotional stability [35], and sleep disorders [36].

Likewise, nomophobia presents a direct and significant link with internet use, social network dependence, and anxiety [37]. Due to these factors, it is considered a digital disease, whose risk factor of suffering is increased in the youth population, between 12 and 18 years old [38], and those subjects whose personality tends to be emotionally dependent [39].

In this technological spectrum, the Internet cannot be forgotten as a technology whose access has been enhanced with the expansion of mobile devices. This has caused addictions to both mobile telephony and Internet access. These new addictions, typical of the digital era, tend to proliferate in economically developed regions, where citizens have the resources and means to have the necessary technology [40].

The characteristics of today's society have caused adolescence to be the most critical age range for suffering from nomophobia, as well as other symptoms such as Internet and video game addiction and the corresponding psychological and emotional implications [41]. Currently, young people are familiar with developing, communicating, interacting, playing, and having fun with other people through digital media. Some young people state that they prefer digital contact to physical contact [42], causing cognitive, behavioral, and physiological alterations [43]. This continuous and abusive action results in the appearance of problems such as a sedentary lifestyle, eating disorders, sleep problems, depression, irritation, aggressiveness, and low self-esteem, among others [44].

As a novelty in the matter, recent studies have focused on measuring the influence of culture on the prevalence of nomophobia. The results show that culture has a relevant role in human behaviors linked to technology $[45,46]$. However, little has been studied on how culture influences the appearance of nomophobia in people [47].

This study explores the state of the art regarding a very frequent pathology among the youngest population, which has been derived as a consequence of the technological development experienced in contemporary society. It reveals that people in contemporary society are not only addicted to the Internet, videogames, and technology in general, but are also afraid of not having the means and technological resources to perform the basic functions such as relating, communicating, having fun, and accessing information.

We are faced with a very recent problem that is typical of the digital age and caused by the rise of mobile technology in people's daily lives. For this reason, this research explores the state of the nomophobia issue in scientific research with the greatest impact.

\section{Method}

This review examines existing literature focused on nomophobia in the Scopus and Web of Science databases. In addition, this work shows the main objectives, methodological design, main variables, 
sample details, and measurement tools of the included investigations. In order to do this, we carry out a systematic review in accordance with the Preferred Reporting Items for Systematic Reviews (PRISMA) guidelines [48] to test the following questions:

$\mathrm{RQ}_{1}$ To what extent is nomophobia a growing public health problem?

$\mathrm{RQ}_{2}$ To what extent are adolescents more vulnerable to nomophobia than other populations?

$\mathrm{RQ}_{3}$ What are the physical and mental health problems and behavioral changes associated with nomophobia?

\subsection{Search Strategy}

During October 2019 we carried out an inquiry that began with the introduction of the keyword "nomophobia" in all possible search fields (title, abstract, keywords, main text, and so on) in both Scopus and the main collection of the Web of Science (WOS, BCI, BIOSIS, CCC, DIIDW, KJD, MEDLINE, RSCI, SCIELO), and contemplating all possible outcomes in the present day. These databases contain most of the current research references and are, in turn, the most consulted by researchers and experts from different areas of knowledge [49]. No limits were given for geographic area, language, year of publication, or method used. We found 149 results (article, meeting, abstract, others). However, the final sample consisted of 42 references.

\subsection{Inclusion Criteria}

The 107 suppressed results were analyzed following a PRISMA protocol for systematic reviews [40]. The main objective was to analyze the articles with the greatest impact that had "nomophobia" as the central focus of their research. In the case of the sample retrieved from the Web of Science $(n=80)$, we deleted references that were not in the Journal Citation Reports indices $(n=36)$ and those that were not articles $(n=8)$ until we reached the final sample. Similarly, we performed this procedure in Scopus, excluding a total of 15 references that did not meet the inclusion criteria with respect to the type of publication. Thus, 91 references were analyzed, 34 of which were deleted as they were articles found in both databases. The 56 remaining records were assessed for eligibility on the basis of the abstract, and in case of doubt, the full text was read. Finally, this figure was reduced to 42 (Figure 1) due to the fact that the main object of study was not nomophobia $(n=14)[3,6,8-10,21,50-57]$.

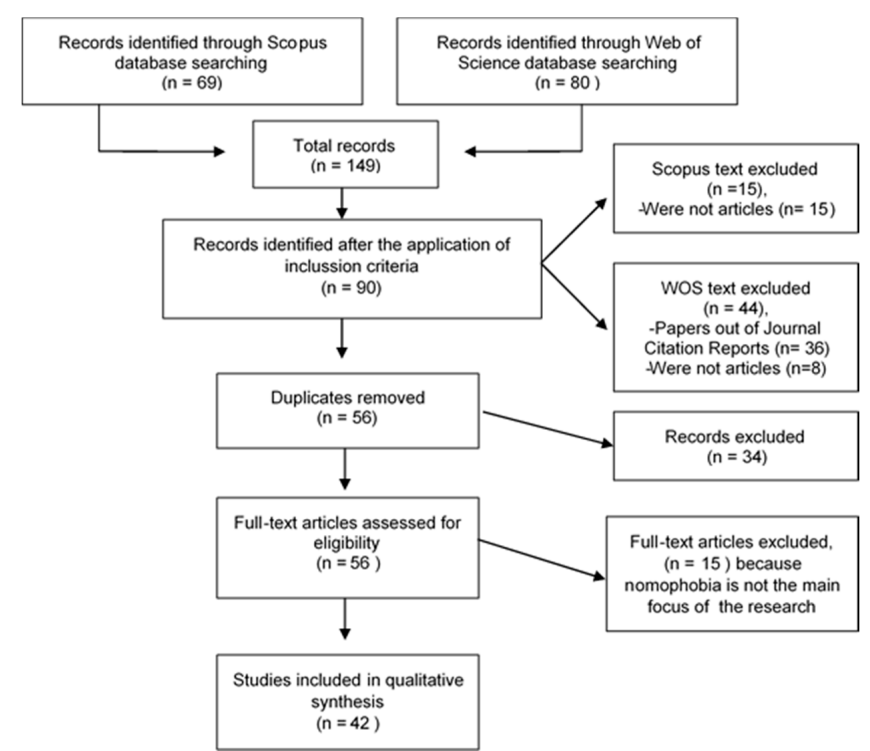

Figure 1. Flow diagram. 


\section{Results}

The articles included in this review were mostly written in English and published between 2010 and 2019. The majority presented results from Turkey $(n=8)$, followed by Spain $(n=7)$ and India $(n=6)$. The most used methods were only quantitative $(n=35)$, nonexperimental $(n=26)$, and cross-sectional studies $(n=32)$. Only $n=3$ used mixed methods and $n=5$ were developed with experimental design (Table A1). At the same time, it should be noted that seven of the articles analyzed attempts to create and/or validate a scale to measure nomophobia in different populations (Table A2). Finally, there are three literature review studies (Table A3).

\subsection{Aims}

Most research aims to analyze the prevalence of nomophobia in different groups, whether students, clinic patients, or random people $[1,18,19,23,29,30,32,33,36,37]$. At the same time, some of them ask if there is any correlation between presenting nomophobia and other alterations of a psychic [5,13,25,26,35,58-60] or physical [61] nature, as well as alterations in learning and attention [31,54], in academic performance [2], coping styles [4], or other psychosocial problems arising in the digital and smartphone era [11,15]. Similarly, there are studies that focus on determining risk factors in relation to certain personality traits [16].

\subsection{Methodological Design}

The research analyzed is eminently exploratory, descriptive, nonexperimental, correlational, and cross-sectional, using the questionnaire as a single research collection instrument $[1,2,4,13$, 16,18-20,23,25,26,29-33,35,37,39,58,61-64], presenting a quantitative methodological design. Others, however, extend this information with mixed methodological design, including qualitative techniques, such as interviews or discussion groups [5,20,24,65]. To a lesser extent, some research applies an experimental design, either through the application of cognitive behavioral therapies $[5,20]$ or the use of control and experimental groups [11,13,15,59,62]. Finally, the articles aimed at validating an instrument for measuring nomophobia stand out. They have adapted the tool proposed by Yildrim and Correia [24] to different country contexts, such as Iran [7], Spain [17,27,28], and Israel [14], reaffirming its factors of validity and reliability [12]. Some review articles were also included [17,38,65].

\subsection{Main Variables}

Most research has nomophobia as the main and only study variable $[1,4,7,14,17-19,22-24,27,28,30$, 31,34,65]. However, other researchers have been interested in examining the relationship between nomophobia and physical factors, such as age [29,33,60], context [29], presence of Carpal tunnel syndrome or median nerve in the wrist [61], and gender [32,33,35,39,58]. Others have studied the relationship between nomophobia and psychic and psychological variables such as anxiety $[20,33,37,39]$, panic disorder [5,20,59], stress [11], depression, avoidance or hostility [12,39], obsessiveness [12,25], FOMO (fear of missing out) [15], personality (extraversion, awareness, emotional stability and regulation, sympathy, and openness to experience) $[12,13,16,26,33,35]$, mindfulness [58], and loneliness and self-happiness [26]. Moreover, others have studied the relationship between nomophobia and sociological, educational, and other factors, including Internet usage and social media [29,37], academic performance [2], learning and attention [13,62], socio-educational variables and collectivism [63], and social threat [11].

\subsection{Sample Details}

The samples used in the various studies vary considerably, both in number, where there is a range from one person to 3216, and in the population on which it is focused. First, in relation to the size of the sample, there are studies that have used a sample between one and 150 people [19,21,27,33,59,61], between 151 and 400 people [11,13,18,23-25,30,31,34,35,60,62,64], 
between 401 and 1000 people [1,2,4,12,14-16,22,26,29,32,36,37,39,58,63,65], or more than 1000 [7]. Second, with regard to population, studies have focused on volunteers of various classes and types $[5,16,20,22,59,60]$, adolescents or youth $[4,7,28,34-36]$, university students where the specialty is not specified $[2,12,14,15,23-26,32,35,39,58,61,62,64,65]$, university nursing students $[18,27,30,31,37]$, medical students [1,19,29,33], engineering students [29], and professional researchers [11]. In other cases, the population is not indicated, given that the study focuses on a systematic review of papers and journals [17].

\subsection{Measurement}

Most studies have conducted their research exclusively using the Nomophobia Questionnaire (NMP-Q) [1,2,4,7,13,14,18,19,22,24,27-32,34,62,64] proposed by [24], which has been adequate and adapted to Persian [7], Indian [2], Spanish [27,28,34], Israeli [14], Italian [12], and Arabic [22] contexts. Other researchers have also added another measuring instrument, such as the Brief Symptom Inventory (BSI) [12,14], Obsessiveness Content Scale (OBS) [25], ultrasonography of the median nerve, Phalen's test, and reverse Phalen's test [61], FOMO Scale [15], UCLA Loneliness Scale (ULS-8), Self-Happiness Scale and Rosenberg' Self-Esteem Scale [26], Stress Scale Social Threat Scale [11], Brief Symptom Inventory [12], Mobile Phone Involvement Questionnaire (MPIQ) [35], Scale of Experiences in Close Relationships (ECR) and Scale of Attention Awareness Mindful-Warning (MAAS) [39], Mindful-Awareness Scale (MAAS) [58], Individualism-Collectivism (INDCOL) [63], Problematic Internet Use Scale (PIUS), Social Appearance Anxiety Scale (SAAS) and Social media use integration scale [37], Emotional Intelligence Questionnaire and Academic iCheating Questionnaire [36], in other scales such as Interviews Scales Inventories Questionnaires [20], Questionnaire to Assess Nomophobia (QANIP), and Temperament and Character Inventory Revised (TCI-R) [16], and in other cases, ad hoc questionnaires of their own elaboration $[5,23,33,59,60,65]$ or ad hoc questionnaires based on NMP-Q [64].

\section{Discussion}

Internet, video games, and now the proliferation of smartphones are causing problems in people's health [40-44]. The rise of mobile technology as a means of interacting and communicating with people [4,6] has led to the emergence of nomophobia [12], cataloged as a typical pathology of the new millennium [15,16], arising from the constant and abusive use of technology [25], which leads to fear, stress, panic, and anxiety when that technology is not available $[11,37,65]$ for communication or accessing information [32].

The analysis of the 42 articles retrieved from Scopus and Web of Science, which have satisfied the inclusion criteria delimited in the PRISMA review process, leads us to the following inferences. The included literature was mostly recent and in the exploratory phase of research, with a primacy of quantitative and cross-sectional studies with a young population (teenagers and university). The general objective of this current line of research is analyzing the prevalence of nomophobia, as well as the relationship of this disorder with the emergence of problems that affect the psychic, physical, and psychosocial development of the subject, as well as their academic performance.

In relation to the instruments reported from the literature analyzed, it has been ascertained that both the analysis tool initially designed by Yildrim and Correia [24] and its derivatives adapted to other study populations $[7,14,22,27,28,34]$ have proven to be valid and reliable. The initial instrument proposed [24] is therefore consolidated as the most-endorsed tool to analyze nomophobia.

However, other instruments have also been created based on measurement scales and ad hoc questionnaires that have been used to obtain information on the prevalence of nomophobia and another linked to it, such as those provided by the research of $[5,11,12,15,16,23,25,26,33,35,37,39,58,60,64,65]$, among others.

The results of the analyzed research highlight aspects of gender [26] and young age [33,60] as predictors of nomophobia. As for the students analyzed in the reported studies, especially those in health studies (nursing and medicine) have high levels of nomophobia [1,19,30,31]. In spite of this, 
engineering students revealed a higher index of this pathology over those of medicine [29]. In the field of education, nomophobia has a negative impact on learning outcomes and academic performance, as has been seen in several studies $[2,13,18,62]$. This phobia has led to medical and psychosocial disorders such as physical injuries [53] and mental disorders [20,59]. The latter generate a set of fears arising from the non-use of mobile devices [23]. It has also been found that extroverted people and people with deficits in consciousness, attention, emotional stability, and self-esteem are more likely to suffer this pathology $[35,39,58]$.

\section{Conclusions}

Based on the results found in this work, it is concluded that nomophobia is a field of study that is currently in the early stages of research, so that most of the research is in the exploratory phase. Young people exposed to intensive and irrational use of technology are only aware of the advantages it offers and are unaware of the risks they may suffer as a consequence [51]. Therefore, a greater volume of research is needed to explore, investigate, and note which are the most determining variables that influence this contemporary pathology; evidence has shown that nomophobia is closely associated with individual mental health, internet addiction, and behavior modification. In addition, it is necessary to promote efficient and healthy use of mobile technology in learning spaces, in order to avoid the emergence of nomophobia and its consequences.

We, therefore, confirm our three initial hypotheses and can state that nomophobia is a public health problem typical of the digital age and that it is caused by an excessive fear of being without access to a smartphone. The great dependence that the current population has generated towards these devices, due to the different possibilities that they offer, makes them more and more vulnerable, with the adolescent population presenting a greater risk factor. Furthermore, due to the nature of the study and the various scientific contributions published so far, nomophobia is related to the development of personality disorders and mental, physical, educational, and social problems.

As for the limitations of the present study, there are those of systematic review studies, for which information may have been lost due to not using the correct descriptors or due to the lack of viability of covering all the databases existing at present. However, due to the novelty and specificity of the term, it was decided to introduce only the concept "nomophobia" as a search engine element. As a future line of research, it is proposed to analyze the influence of nomophobia on aspects related to people's day-to-day life, such as sleeping hours or food.

Author Contributions: Conceptualization, J.L.B. and A.-M.R.-G.; methodology, A.-J.M.-G.; software, A.-J.M.-G.; formal analysis, A.-M.R.-G.; investigation, A.-M.R.-G.; resources, J.L.B.; data curation, A.-J.M.-G.; writing-original draft preparation, A.-J.M.-G., J.L.B., and A.-M.R.-G.; writing-review and editing, J.L.B. and A.-J.M.-G.; visualization, J.L.B.; supervision, A.-M.R.-G. All authors have read and agreed to the published version of the manuscript.

Funding: This research has received public funding from the Ministry of Education of the Government of Spain (FPU14/04626).

Acknowledgments: We acknowledge the researchers of the research group AREA (HUM-672), which belongs to the Ministry of Education and Science of the Junta de Andalucía and is registered in the Department of Didactics and School Organization of the Faculty of Education Sciences of the University of Granada.

Conflicts of Interest: The authors declare no conflict of interest. 


\section{Appendix A}

Table A1. Experimental or nonexperimental studies.

\begin{tabular}{|c|c|c|c|c|c|c|c|}
\hline Reference & Country & $\operatorname{Aim}(s)$ & Methodology & Sample Details & Main Variables & Measurement & Main Findings \\
\hline [12] & Italy & $\begin{array}{l}\text { The authors hypothesized to find } \\
\text { a statistically significant } \\
\text { association between nomophobic } \\
\text { use of smartphones and } \\
\text { psychopathological symptoms as } \\
\text { measured by the BSI. }\end{array}$ & $\begin{array}{l}\text { Cross-sectional, descriptive, } \\
\text { correlational, and } \\
\text { quantitative study with } \\
\text { nonexperimental design. }\end{array}$ & $\begin{array}{l}403 \text { volunteers, } \\
\text { primarily } \\
\text { undergraduate students }\end{array}$ & $\begin{array}{l}\text { Anxiety. Depression. } \\
\text { Hostility. Sensitivity. } \\
\text { Interpersonal. } \\
\text { Obsession-compulsion. } \\
\text { Phobic anxiety. Paranoia. } \\
\text { Psychosis. Somatization }\end{array}$ & $\begin{array}{l}\text { Nomophobia } \\
\text { Questionnaire (NMP-Q). } \\
\text { Brief Symptom } \\
\text { Inventory (BSI) }\end{array}$ & $\begin{array}{l}\text { The results show that BSI is a reliable } \\
\text { and valid instrument with acceptable } \\
\text { psychometric properties, and can be } \\
\text { administered to nomophobic } \\
\text { populations. }\end{array}$ \\
\hline [31] & Spain & $\begin{array}{l}\text { To analyze the relationship } \\
\text { between the level of nomophobia } \\
\text { and the distraction associated } \\
\text { with smartphone use among } \\
\text { nursing students during their } \\
\text { clinical practicum. }\end{array}$ & $\begin{array}{l}\text { Cross-sectional, descriptive, } \\
\text { correlational, and } \\
\text { quantitative study with } \\
\text { nonexperimental design }\end{array}$ & 304 nursing students & Nomophobia & $\begin{array}{l}\text { Nomophobia } \\
\text { Questionnaire } \\
\text { (NMP-Q). }\end{array}$ & $\begin{array}{l}\text { Nursing students who show high } \\
\text { levels of nomophobia also regularly } \\
\text { use their smartphones during their } \\
\text { clinical practice, although they also } \\
\text { believe it is necessary to implement } \\
\text { policies that restrict the use of } \\
\text { smartphones while working. }\end{array}$ \\
\hline [18] & India & $\begin{array}{l}\text { To determine the impact of } \\
\text { nomophobia on education among } \\
\text { SPPC (students pursuing } \\
\text { physiotherapy course). }\end{array}$ & $\begin{array}{l}\text { Cross-sectional, descriptive, } \\
\text { correlational, and } \\
\text { quantitative study with } \\
\text { nonexperimental design }\end{array}$ & 157 nursing students & Nomophobia & $\begin{array}{l}\text { Nomophobia } \\
\text { Questionnaire } \\
\text { (NMP-Q). }\end{array}$ & $\begin{array}{l}\text { Nursing students present } \\
\text { nomophobia. There may be a } \\
\text { negative impact between } \\
\text { nomophobia and academic } \\
\text { performance. }\end{array}$ \\
\hline [23] & Malaysia & $\begin{array}{l}\text { To see the relationship between } \\
\text { smartphone usage factors and } \\
\text { nomophobia. }\end{array}$ & $\begin{array}{l}\text { Cross-sectional, descriptive, } \\
\text { correlational, and } \\
\text { quantitative study with } \\
\text { nonexperimental design }\end{array}$ & 200 university students & Nomophobia & Ad hoc questionnaire & $\begin{array}{l}\text { The fear of the inability to } \\
\text { communicate, the fear of loss of } \\
\text { connection, the fear of being alone, } \\
\text { and the fear of loss of convenience } \\
\text { have a significant relationship with } \\
\text { nomophobia. }\end{array}$ \\
\hline
\end{tabular}


Table A1. Cont.

\begin{tabular}{|c|c|c|c|c|c|c|c|}
\hline Reference & Country & Aim (s) & Methodology & Sample Details & Main Variables & Measurement & Main Findings \\
\hline [39] & Turkey & $\begin{array}{l}\text { To investigate the mediating } \\
\text { effect of mindfulness on the } \\
\text { relationship between attachment } \\
\text { and nomophobia. In addition, the } \\
\text { study also focuses on gender } \\
\text { differences in attachment, } \\
\text { mindfulness, and nomophobia }\end{array}$ & $\begin{array}{l}\text { Cross-sectional, descriptive, } \\
\text { correlational, and } \\
\text { quantitative study with } \\
\text { nonexperimental design }\end{array}$ & 450 university students & $\begin{array}{l}\text { Anxiety. Evasive. } \\
\text { Mindfulness. Nomophobia. } \\
\text { Gender. }\end{array}$ & $\begin{array}{l}\text { Scale of Experiences in } \\
\text { Close Relationships } \\
\text { (ECR) Scale of } \\
\text { Awareness of Attention } \\
\text { Mindfuld-Advertencia } \\
\text { (MAAS) Nomophobia } \\
\text { Questionnaire (NMP-Q) }\end{array}$ & $\begin{array}{l}\text { In general, people who are } \\
\text { emotionally more dependent and } \\
\text { crave greater closeness and attention } \\
\text { in daily life tend to show higher } \\
\text { levels of fear or discomfort when } \\
\text { they do not have access to their } \\
\text { smartphones. However, gender has a } \\
\text { differential impact on the relationship } \\
\text { between evasive attachment and } \\
\text { nomophobia. }\end{array}$ \\
\hline [58] & Turkey & $\begin{array}{l}\text { To investigate the impact of } \\
\text { individual differences in } \\
\text { mindfulness on nomophobia }\end{array}$ & $\begin{array}{l}\text { Cross-sectional, descriptive, } \\
\text { correlational, and } \\
\text { quantitative study with } \\
\text { nonexperimental design }\end{array}$ & 491 university students & $\begin{array}{l}\text { Mindfulness. Gender. } \\
\text { Nomophobia. }\end{array}$ & $\begin{array}{l}\text { Nomophobia } \\
\text { Questionnaire (NMP-Q). } \\
\text { Attention Awareness } \\
\text { Scale } \\
\text { Mindful-Awareness } \\
\text { Scale (MAAS) }\end{array}$ & $\begin{array}{l}\text { The results revealed that mindfulness } \\
\text { had a significant negative correlation } \\
\text { with nomophobia for both men and } \\
\text { women. Subjects with lower scores in } \\
\text { Attention showed greater anxiety } \\
\text { when they were unable to } \\
\text { communicate. }\end{array}$ \\
\hline [47] & Turkey & $\begin{array}{l}\text { This study aims at contributing to } \\
\text { literature by investigating the role } \\
\text { of espoused culture in } \\
\text { influencing nomophobia. }\end{array}$ & $\begin{array}{l}\text { Cross-sectional, descriptive, } \\
\text { correlational, and } \\
\text { quantitative study with } \\
\text { nonexperimental design }\end{array}$ & 490 university students & $\begin{array}{l}\text { Nomophobia Individual } \\
\text { Collectivism }\end{array}$ & $\begin{array}{l}\text { Nomophobia } \\
\text { Questionnaire (NMP-Q) } \\
\text { Individualism-Collectivism } \\
\text { (INDCOL) }\end{array}$ & $\begin{array}{l}\text { The results suggest that the } \\
\text { relationship between vertical } \\
\text { collectivism and nomophobia is } \\
\text { significant and positive, while the } \\
\text { relationship between horizontal } \\
\text { collectivism and nomophobia was } \\
\text { not significant. }\end{array}$ \\
\hline [1] & India & $\begin{array}{l}\text { To evaluate nomophobia among } \\
\text { medical students who are using } \\
\text { smartphones. }\end{array}$ & $\begin{array}{l}\text { Cross-sectional, descriptive, } \\
\text { correlational, and } \\
\text { quantitative study with } \\
\text { nonexperimental design }\end{array}$ & 451 medical students & Nomophobia & $\begin{array}{l}\text { Nomophobia } \\
\text { Questionnaire (NMP-Q) }\end{array}$ & $\begin{array}{l}\text { Medical students suffer from } \\
\text { nomophobia, with varying degrees of } \\
\text { severity. }\end{array}$ \\
\hline [4] & Italy & $\begin{array}{l}\text { To explore coping styles } \\
\text { implemented in subjects with } \\
\text { nomophobia }\end{array}$ & $\begin{array}{l}\text { Cross-sectional, descriptive, } \\
\text { correlational, and } \\
\text { quantitative study with } \\
\text { nonexperimental design }\end{array}$ & 403 jóvenes italianos & Nomophobia & $\begin{array}{l}\text { Nomophobia } \\
\text { Questionnaire (NMP-Q) }\end{array}$ & $\begin{array}{l}\text { Nomophobic subjects adopt } \\
\text { maladaptive coping strategies when } \\
\text { faced with stress. Recognition of how } \\
\text { nomophobic subjects react provides } \\
\text { insight and introduces an approach } \\
\text { to preventive and interventional } \\
\text { measures in this population. }\end{array}$ \\
\hline
\end{tabular}


Table A1. Cont.

\begin{tabular}{|c|c|c|c|c|c|c|c|}
\hline Reference & Country & Aim (s) & Methodology & Sample Details & Main Variables & Measurement & Main Findings \\
\hline [33] & Iran & $\begin{array}{l}\text { To investigate nomophobia (no } \\
\text { mobile phone phobia) among } \\
\text { medical students of Islamic Azad } \\
\text { University, Tehran Branch }\end{array}$ & $\begin{array}{l}\text { Cross-sectional, descriptive, } \\
\text { correlational, and } \\
\text { quantitative study with } \\
\text { nonexperimental design }\end{array}$ & 100 medical students & $\begin{array}{l}\text { Age. Gender. Education. } \\
\text { Discomfort. Anxiety. } \\
\text { Insecurity. }\end{array}$ & Ad hoc questionnaire & $\begin{array}{l}\text { The study results showed that } \\
\text { participants with a lower mean age } \\
\text { felt more discomfort, anger, anxiety, } \\
\text { and insecurity due to lack of access to } \\
\text { smartphones and other related } \\
\text { problems compared with other } \\
\text { people. }\end{array}$ \\
\hline [29] & India & $\begin{array}{l}\text { To find out the prevalence of } \\
\text { nomophobia among } \\
\text { smartphone-using medical and } \\
\text { engineering undergraduates of } \\
\text { West Bengal and to compare the } \\
\text { nomophobic behaviors, } \\
\text { predictors, and smartphone } \\
\text { usage among them. }\end{array}$ & $\begin{array}{l}\text { Cross-sectional, descriptive, } \\
\text { correlational, and } \\
\text { quantitative study with } \\
\text { nonexperimental design }\end{array}$ & $\begin{array}{l}608 \text { university students } \\
\text { (medical } 303 \text { and } 305 \\
\text { engineering students) }\end{array}$ & $\begin{array}{l}\text { Nomophobia Age. Sex. } \\
\text { Residence. Year of study. } \\
\text { Socioeconomic variables }\end{array}$ & $\begin{array}{l}\text { Nomophobia } \\
\text { Questionnaire (NMP-Q) }\end{array}$ & $\begin{array}{l}\text { Engineering students showed a } \\
\text { higher proportion of nomophobes } \\
\text { than medical students. A higher } \\
\text { proportion of nomophobes between } \\
\text { the two groups were women, those } \\
\text { with smartphones beyond the age of } \\
2 \text {, those with high monthly bills, and } \\
\text { those who spend more than } 4 \text { hours a } \\
\text { day on the smartphone. }\end{array}$ \\
\hline [19] & India & $\begin{array}{l}\text { To assess the prevalence of } \\
\text { nomophobia in medical students. }\end{array}$ & $\begin{array}{l}\text { Cross-sectional, descriptive, } \\
\text { correlational, and } \\
\text { quantitative study with } \\
\text { nonexperimental design }\end{array}$ & 145 medical students & Nomophobia & $\begin{array}{l}\text { Nomophobia } \\
\text { Questionnaire (NMP-Q) }\end{array}$ & $\begin{array}{l}\text { Nomophobia is prevalent in 1st year } \\
\text { medical students. }\end{array}$ \\
\hline [36] & France, USA & $\begin{array}{l}\text { The author asks two provocative } \\
\text { questions: Does Generation Z } \\
\text { (Gen Z) adolescents' emotional } \\
\text { intelligence (EI) provoke } \\
\text { iCheating? Can emotional } \\
\text { intelligence curb nomophobia } \\
\text { and thereby mitigate academic } \\
\text { iCheating? }\end{array}$ & $\begin{array}{l}\text { Cross-sectional, descriptive, } \\
\text { correlational, and } \\
\text { quantitative study with } \\
\text { nonexperimental design }\end{array}$ & 472 high school students & $\begin{array}{l}\text { Nomophobia Emotional } \\
\text { Intelligence ICheating }\end{array}$ & $\begin{array}{l}\text { Nomophobia } \\
\text { Questionnaire (NMP-Q) } \\
\text { Emotional intelligence } \\
\text { questionnaire. } \\
\text { ICheating academic } \\
\text { questionnaire. }\end{array}$ & $\begin{array}{l}\text { Emotional intelligence }(\mathrm{EI}) \text { directly } \\
\text { encourages iCheating but indirectly } \\
\text { reduces nomophobia. }\end{array}$ \\
\hline [30] & $\begin{array}{l}\text { Spain, } \\
\text { Portugal }\end{array}$ & $\begin{array}{l}\text { To compare the levels of } \\
\text { nomophobia experienced by } \\
\text { nursing students at the } \\
\text { University of Almeria, Spain and } \\
\text { the Polytechnic Institute of } \\
\text { Braganza, Portugal. }\end{array}$ & $\begin{array}{l}\text { Cross-sectional, descriptive, } \\
\text { correlational, and } \\
\text { quantitative study with } \\
\text { non-experimental design }\end{array}$ & $\begin{array}{l}258 \text { university students } \\
\text { from Spain and Portugal }\end{array}$ & Nomophobia & $\begin{array}{l}\text { Nomophobia } \\
\text { Questionnaire (NMP-Q) }\end{array}$ & $\begin{array}{l}\text { The dimensions explored indicate } \\
\text { significant levels of nomophobia } \\
\text { among both populations of nursing } \\
\text { students, with higher levels among } \\
\text { the Portuguese population than } \\
\text { among the Spanish population. }\end{array}$ \\
\hline [63] & $\begin{array}{l}\text { Republic of } \\
\text { Korea; Hong } \\
\text { Kong. }\end{array}$ & $\begin{array}{l}\text { This study explicates } \\
\text { nomophobia by developing a } \\
\text { research model that identifies } \\
\text { several determinants of } \\
\text { smartphone separation anxiety } \\
\text { and by conducting semantic } \\
\text { network analyses on smartphone } \\
\text { users' verbal descriptions of the } \\
\text { meaning of their smartphones }\end{array}$ & $\begin{array}{l}\text { Cross-sectional, descriptive, } \\
\text { correlational, and } \\
\text { quantitative study with } \\
\text { nonexperimental design }\end{array}$ & 301 university students. & $\begin{array}{l}\text { Nomophobia Anxiety } \\
\text { Emotions }\end{array}$ & $\begin{array}{l}\text { Ad hoc questionnaire, } \\
\text { based on Yildrim y } \\
\text { Correia (2015) }\end{array}$ & $\begin{array}{l}\text { When users perceive smartphones as } \\
\text { being extended, they are more likely } \\
\text { to connect to devices, which, in turn, } \\
\text { leads to nomophobia by increasing } \\
\text { the tendency to search for phone } \\
\text { proximity. In addition, words related } \\
\text { to memory, self, and proximity search } \\
\text { are, in fact, more frequent in the high } \\
\text { nomophobia group compared with } \\
\text { the low nomophobia group. }\end{array}$ \\
\hline
\end{tabular}


Table A1. Cont.

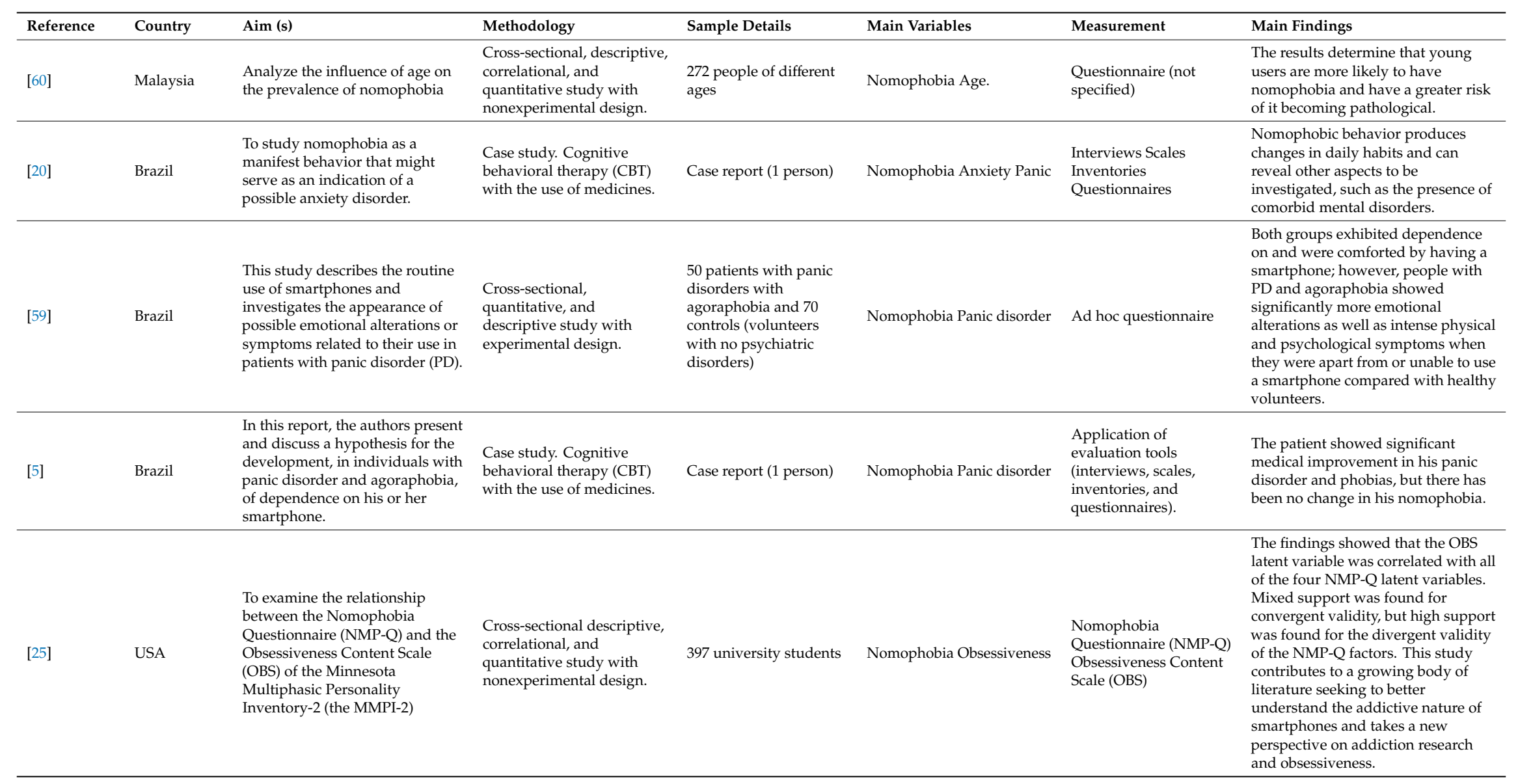


Table A1. Cont.

\begin{tabular}{|c|c|c|c|c|c|c|c|}
\hline Reference & Country & Aim (s) & Methodology & Sample Details & Main Variables & Measurement & Main Findings \\
\hline [61] & South Korea & $\begin{array}{l}\text { To examine the effect of excessive } \\
\text { use of smartphones on the carpal } \\
\text { tunnel and median nerve in the } \\
\text { wrist. }\end{array}$ & $\begin{array}{l}\text { Cross-sectional descriptive, } \\
\text { correlational, and } \\
\text { quantitative study with } \\
\text { nonexperimental design. }\end{array}$ & 125 university students & $\begin{array}{l}\text { Nomophobia Carpal tunnel } \\
\text { Median nerve in the wrist }\end{array}$ & $\begin{array}{l}\text { Nomophobia } \\
\text { Questionnaire (NMP-Q) } \\
\text { Ultrasonography of the } \\
\text { median nerve, Phalen's } \\
\text { tests, and reverse } \\
\text { Phalen's tests }\end{array}$ & $\begin{array}{l}\text { Excessive use of smartphones may } \\
\text { act as a cause to trigger carpal tunnel } \\
\text { syndrome due to pressure on the } \\
\text { carpal tunnel in the wrist joint; thus, } \\
\text { precautions are necessary when } \\
\text { using smartphones. }\end{array}$ \\
\hline [13] & USA & $\begin{array}{l}\text { To examine the impact of different } \\
\text { smartphone policies on learning } \\
\text { and emotion regulation style }\end{array}$ & $\begin{array}{l}\text { Cross-sectional and } \\
\text { quantitative study with } \\
\text { experimental design. }\end{array}$ & $\begin{array}{l}160 \text { university students } \\
\text { in } 4 \text { groups of } 40 \\
\text { participants. }\end{array}$ & $\begin{array}{l}\text { Nomophobia Learning } \\
\text { Emotion-regulation }\end{array}$ & $\begin{array}{l}\text { Nomophobia } \\
\text { Questionnaire (NMP-Q) }\end{array}$ & $\begin{array}{l}\text { Participants who had their } \\
\text { smartphone taken away performed } \\
\text { best in the test with no other } \\
\text { differences. None of the emotional } \\
\text { regulation measures moderated the } \\
\text { results. These findings provide } \\
\text { important insight as to how } \\
\text { smartphone policies can optimize } \\
\text { learning in the classroom }\end{array}$ \\
\hline [62] & USA & $\begin{array}{l}\text { To examine how the presence of } \\
\text { having a smartphone, the } \\
\text { distractibility of text messages, } \\
\text { and individual differences in } \\
\text { nomophobia might impact } \\
\text { learning at different times during } \\
\text { a short lecture. }\end{array}$ & $\begin{array}{l}\text { Cross-sectional descriptive, } \\
\text { correlational, and } \\
\text { quantitative study with } \\
\text { experimental design. }\end{array}$ & $\begin{array}{l}160 \text { university students } \\
\text { divided into } 4 \text { groups of } \\
40 \text { participants. }\end{array}$ & $\begin{array}{l}\text { Nomophobia Learning } \\
\text { Attention }\end{array}$ & $\begin{array}{l}\text { Nomophobia } \\
\text { Questionnaire (NMP-Q) }\end{array}$ & $\begin{array}{l}\text { Participants who kept their } \\
\text { smartphones performed worse on the } \\
\text { quiz for material presented in the } \\
\text { third quarter of the lecture than those } \\
\text { without smartphones. Distracted } \\
\text { participants performed worse in the } \\
\text { test for the same material than those } \\
\text { who were not distracted. Participants } \\
\text { higher in nomophobia, especially on } \\
\text { subscales having to do with losing } \\
\text { connectedness and giving up } \\
\text { convenience, performed worse on the } \\
\text { quiz for material that occurred in the } \\
\text { third quarter of the lecture. Findings } \\
\text { indicate that having smartphones in } \\
\text { a short lecture has its largest impact } \\
\text { on attention and learning } 10-15 \text { min } \\
\text { into the lecture. }\end{array}$ \\
\hline [15] & Turkey & $\begin{array}{l}\text { To examine the relationship } \\
\text { between nomophobia and FOMO } \\
\text { (fear of missing out) }\end{array}$ & $\begin{array}{l}\text { Cross-sectional, descriptive, } \\
\text { correlational, and } \\
\text { quantitative study with } \\
\text { nonexperimental design }\end{array}$ & 538 university students & Nomophobia FOMO & $\begin{array}{l}\text { Nomophobia } \\
\text { Questionnaire (NMP-Q) } \\
\text { FOMO Scale }\end{array}$ & $\begin{array}{l}\text { The results show that a positive } \\
\text { moderate level of the relationship } \\
\text { was found between nomophobia and } \\
\text { FOMO levels }\end{array}$ \\
\hline
\end{tabular}


Table A1. Cont.

\begin{tabular}{|c|c|c|c|c|c|c|c|}
\hline Reference & Country & $\operatorname{Aim}(\mathrm{s})$ & Methodology & Sample Details & Main Variables & Measurement & Main Findings \\
\hline [16] & Spain & $\begin{array}{l}\text { The current study set out to } \\
\text { establish the relationship between } \\
\text { temperament and personality and } \\
\text { the development of nomophobia }\end{array}$ & $\begin{array}{l}\text { Cross-sectional, descriptive, } \\
\text { correlational, and } \\
\text { quantitative study with } \\
\text { nonexperimental design }\end{array}$ & $\begin{array}{l}968 \text { participants selected } \\
\text { from the Andalusian } \\
\text { population. }\end{array}$ & $\begin{array}{l}\text { Nomophobia Temperament } \\
\text { Personality }\end{array}$ & $\begin{array}{l}\text { Questionnaire to Assess } \\
\text { Nomophobia (QANIP) } \\
\text { Temperament and } \\
\text { Character Inventory } \\
\text { Revised (TCI-R) }\end{array}$ & $\begin{array}{l}\text { The authors found that cooperation is } \\
\text { a characteristic that significantly } \\
\text { reduces nomophobic levels, } \\
\text { particularly for the two factors of } \\
\text { smartphone addiction and negative } \\
\text { consequences. Furthermore, Reward } \\
\text { Dependence appears to be positively } \\
\text { related to two of the factors involved } \\
\text { in nomophobia, namely smartphone } \\
\text { addiction and loss of control, } \\
\text { suggesting a relationship between } \\
\text { nomophobia and personality. }\end{array}$ \\
\hline [26] & $\begin{array}{l}\text { Turkey, } \\
\text { Pakistan }\end{array}$ & $\begin{array}{l}\text { This study focused on examining } \\
\text { the prevalence of nomophobia } \\
\text { among university students; and } \\
\text { the relationship between } \\
\text { nomophobia, self-esteem, } \\
\text { loneliness, and self-happiness } \\
\text { with respect to gender and year } \\
\text { of study of the university } \\
\text { students in Pakistan and Turkey. }\end{array}$ & $\begin{array}{l}\text { Cross-sectional, descriptive, } \\
\text { correlational, and } \\
\text { quantitative study with } \\
\text { nonexperimental design }\end{array}$ & $\begin{array}{l}729 \text { university students } \\
\text { from Turkey and } \\
\text { Pakistan. }\end{array}$ & $\begin{array}{l}\text { Nomophobia Self-esteem } \\
\text { Loneliness Self-happiness }\end{array}$ & $\begin{array}{l}\text { Nomophobia } \\
\text { Questionnaire (NMP-Q) } \\
\text { UCLA Loneliness Scale } \\
\text { (ULS-8) Self-Happiness } \\
\text { Scale Rosenberg' } \\
\text { Self-Esteem Scale }\end{array}$ & $\begin{array}{l}\text { According to multivariate effects } \\
\text { results, the main effect of gender on } \\
\text { self-esteem and nomophobia was } \\
\text { statistically significant, which } \\
\text { indicates that differences between } \\
\text { male and female students with } \\
\text { respect to self-esteem and } \\
\text { nomophobia were significant. The } \\
\text { study demonstrated differences } \\
\text { between Turkish and Pakistani } \\
\text { students' scores on nomophobia, } \\
\text { loneliness, and self-happiness were } \\
\text { significant, while differences in } \\
\text { self-esteem across countries were not } \\
\text { statistically significant. }\end{array}$ \\
\hline [2] & India & $\begin{array}{l}\text { To assess the pattern of usage of } \\
\text { smartphones and its effects on the } \\
\text { academic performance of } \\
\text { students }\end{array}$ & $\begin{array}{l}\text { Cross-sectional, descriptive, } \\
\text { and quantitative study with } \\
\text { nonexperimental design }\end{array}$ & 554 university students & $\begin{array}{l}\text { Nomophobia Academic } \\
\text { performance }\end{array}$ & $\begin{array}{l}\text { Nomophobia } \\
\text { Questionnaire (NMP-Q) } \\
\text { adaptation }\end{array}$ & $\begin{array}{l}\text { The pattern of usage of smartphones } \\
\text { among students showed alarming } \\
\text { indication that students have been } \\
\text { addicted to a smartphone, which, in } \\
\text { turn, affects their academic } \\
\text { performance in a negative way }\end{array}$ \\
\hline [64] & Peru & $\begin{array}{l}\text { To identify symptoms that have } \\
\text { not yet been detected by intensive } \\
\text { smartphone use }\end{array}$ & $\begin{array}{l}\text { Cross-sectional, descriptive, } \\
\text { and mixed methods with } \\
\text { nonexperimental design }\end{array}$ & 461 university students & Nomophobia & $\begin{array}{l}\text { Focus group Ad hoc } \\
\text { questionnaire }\end{array}$ & $\begin{array}{l}\text { Three symptomatic factors of } \\
\text { nomophobia were identified: feelings } \\
\text { of anxiety, compulsive smartphone } \\
\text { use, and feelings of anxiety and } \\
\text { panic. }\end{array}$ \\
\hline
\end{tabular}


Table A1. Cont.

\begin{tabular}{|c|c|c|c|c|c|c|c|}
\hline Reference & Country & Aim (s) & Methodology & Sample Details & Main Variables & Measurement & Main Findings \\
\hline [11] & Canada & $\begin{array}{l}\text { This study examined the process } \\
\text { by which nomophobia's effect on } \\
\text { stress unfolds }\end{array}$ & $\begin{array}{l}\text { Cross-sectional descriptive, } \\
\text { correlational, and } \\
\text { quantitative study with } \\
\text { experimental design }\end{array}$ & $\begin{array}{l}270 \text { young business } \\
\text { professionals divided } \\
\text { into four groups. }\end{array}$ & $\begin{array}{l}\text { Nomophobia Stress Social } \\
\text { Threat }\end{array}$ & $\begin{array}{l}\text { Nomophobia } \\
\text { Questionnaire (NMP-Q) } \\
\text { Stress Scale Social } \\
\text { Threat Scale }\end{array}$ & $\begin{array}{l}\text { The authors found that nomophobia } \\
\text { leads to stress via social threat when } \\
\text { uncertainty or lack of control are } \\
\text { present. Only under the condition of } \\
\text { low uncertainty and high control } \\
\text { does nomophobia not lead to stress. }\end{array}$ \\
\hline [32] & Turkey & $\begin{array}{l}\text { To investigate the prevalence of } \\
\text { nomophobia among young } \\
\text { adults in Turkey }\end{array}$ & $\begin{array}{l}\text { Cross-sectional descriptive, } \\
\text { correlational, and } \\
\text { quantitative study with } \\
\text { nonexperimental design. }\end{array}$ & 537 university students & Nomophobia Gender & $\begin{array}{l}\text { Nomophobia } \\
\text { Questionnaire (NMP-Q) }\end{array}$ & $\begin{array}{l}\text { The results revealed } 42.6 \% \text { of young } \\
\text { adults had nomophobia, and their } \\
\text { greatest fears were related to } \\
\text { communication and information } \\
\text { access. The study also found that } \\
\text { gender and the duration of } \\
\text { smartphone ownership had an effect } \\
\text { on young adults' nomophobic } \\
\text { behaviors, whereas age and the } \\
\text { duration of smartphone ownership } \\
\text { had no effect }\end{array}$ \\
\hline
\end{tabular}


Table A2. Adaptation and validation of questionnaires to measure nomophobia.

\begin{tabular}{|c|c|c|c|c|c|c|c|}
\hline Reference & Country & Aim (s) & Methodology & Sample Details & Main Variables & Measurement & Main Findings \\
\hline [14] & Israel & $\begin{array}{l}\text { Translate and validate the } \\
\text { Nomophobia Questionnaire (NMP-Q } \\
\text { created by Yildrim and Correia } \\
\text { (2015). }\end{array}$ & $\begin{array}{l}\text { Quantitative method, of } \\
\text { correlational character. }\end{array}$ & $\begin{array}{l}403 \text { volunteers, } \\
\text { primarily } \\
\text { undergraduate students } \\
\text { (no specialty specified) }\end{array}$ & Nomophobia & $\begin{array}{l}\text { Nomophobia } \\
\text { Questionnaire (NMP-Q) }\end{array}$ & $\begin{array}{l}\text { The Italian version of NMP-Q has } \\
\text { proven to be viable. }\end{array}$ \\
\hline [22] & Kuwait & $\begin{array}{l}\text { Develop and validate the Arabic } \\
\text { version of the NMP-Q questionnaire }\end{array}$ & Quantitative method. & $\begin{array}{l}512 \text { Kuwaiti volunteers } \\
\text { with an average age of } \\
20 \text { years }\end{array}$ & Nomophobia & $\begin{array}{l}\text { Nomophobia } \\
\text { Questionnaire (NMP-Q) }\end{array}$ & $\begin{array}{l}\text { The Arabic version of NMP-Q has } \\
\text { proven to be consistent and reliable. }\end{array}$ \\
\hline [34] & Spain & $\begin{array}{l}\text { Adapt the NMP-Q questionnaire to } \\
\text { Spanish }\end{array}$ & $\begin{array}{l}\text { Quantitative method, of } \\
\text { correlational character. }\end{array}$ & $\begin{array}{l}306 \text { students from } \\
\text { Navarra, Asturias, and } \\
\text { Salamanca }\end{array}$ & Nomophobia & $\begin{array}{l}\text { Nomophobia } \\
\text { Questionnaire (NMP-Q) }\end{array}$ & $\begin{array}{l}\text { The Spanish version of the } \\
\text { nomophobia questionnaire (NMP-Q) } \\
\text { was found to be valid and reliable for } \\
\text { assessing nomophobia. }\end{array}$ \\
\hline [27] & Spain & $\begin{array}{l}\text { Translate the original (written in } \\
\text { English) version of the Nomophobia } \\
\text { questionnaire, adapting it culturally } \\
\text { to the Spanish sociolinguistic context, } \\
\text { and analyze the psychometric } \\
\text { properties of the Spanish version } \\
\text { with a sample of nursing students. }\end{array}$ & $\begin{array}{l}\text { Quantitative method, of } \\
\text { correlational character }\end{array}$ & $\begin{array}{l}65 \text { nursing students and } \\
20 \text { subject matter experts }\end{array}$ & Nomophobia & $\begin{array}{l}\text { Nomophobia } \\
\text { Questionnaire (NMP-Q) }\end{array}$ & $\begin{array}{l}\text { The results of this study mean that a } \\
\text { suitable tool can be applied to } \\
\text { nursing professionals with the aim of } \\
\text { facilitating the diagnosis of addictive } \\
\text { behaviors in relation to the mobility } \\
\text { of telephone use. }\end{array}$ \\
\hline [7] & Iran & $\begin{array}{l}\text { This study aimed to confirm the } \\
\text { construct validity of the Persian } \\
\text { NMP-Q using Rasch and } \\
\text { confirmatory factor analysis (CFA) } \\
\text { models. }\end{array}$ & $\begin{array}{l}\text { Cross-sectional and } \\
\text { quantitative study. }\end{array}$ & 3216 Iranian adolescents & Nomophobia & $\begin{array}{l}\text { Nomophobia } \\
\text { Questionnaire (NMP-Q) }\end{array}$ & $\begin{array}{l}\text { The authors concluded that the } \\
\text { Persian NMP-Q can be used to assess } \\
\text { nomophobia among adolescents. } \\
\text { Moreover, NMP-Q users may } \\
\text { compare their scores between } \\
\text { genders in the knowledge that there } \\
\text { are no score differences contributed } \\
\text { by different understandings of } \\
\text { NMP-Q items. }\end{array}$ \\
\hline [28] & Spain & $\begin{array}{l}\text { Adapt and validate the scale to } \\
\text { measure nomophobia (NMP-Q) to } \\
\text { the Spanish context. }\end{array}$ & $\begin{array}{l}\text { Cross-sectional and } \\
\text { quantitative study. }\end{array}$ & 372 estudiantes de ESO. & Nomophobia & $\begin{array}{l}\text { Nomophobia } \\
\text { Questionnaire (NMP-Q) }\end{array}$ & $\begin{array}{l}\text { The results allowed the validation of } \\
\text { the Yildirim and Correia scale. }\end{array}$ \\
\hline [24] & Turkey & $\begin{array}{l}\text { This study sought to contribute to the } \\
\text { nomophobia research literature by } \\
\text { identifying and describing the } \\
\text { dimensions of nomophobia and } \\
\text { developing a questionnaire to } \\
\text { measure nomophobia. }\end{array}$ & $\begin{array}{l}\text { Mixed methods with } \\
\text { exploratory design. }\end{array}$ & 301 university students & Nomophobia & $\begin{array}{l}\text { Interview } \\
\text { Nomophobia } \\
\text { Questionnaire (NMP-Q) }\end{array}$ & $\begin{array}{l}\text { Four dimensions of nomophobia } \\
\text { were identified: not being able to } \\
\text { communicate, losing connectedness, } \\
\text { not being able to access information } \\
\text { and giving up convenience. } \\
\text { The NMP-Q was shown to produce } \\
\text { valid and reliable scores; and thus, } \\
\text { can be used to assess the severity of } \\
\text { nomophobia. }\end{array}$ \\
\hline
\end{tabular}


Table A3. Literature review.

\begin{tabular}{|c|c|c|c|c|}
\hline Reference & Country & $\operatorname{Aim}(s)$ & Methodology & Main Findings \\
\hline [38] & Cyprus & $\begin{array}{l}\text { To examine the types of digital diseases arising } \\
\text { from the use of social media and problematic use } \\
\text { as a result of digitization, including nomophobia, } \\
\text { cyberchondria, and the fear of getting lost. In } \\
\text { English they are nomophobia; cyberchondria; } \\
\text { FOMO (fear of missing out). }\end{array}$ & Literature review & $\begin{array}{l}\text { The addiction takes them to a dead end, causing the } \\
\text { appearance of digital diseases that lead to various } \\
\text { psychological disorders in individuals. Additional studies } \\
\text { on digital diseases would provide essential data on their } \\
\text { symptoms in individuals. An overview of the literature } \\
\text { shows that most studies examine nomophobia, FOMO, and } \\
\text { cyberchondria as new diseases. }\end{array}$ \\
\hline [65] & Italy & $\begin{array}{l}\text { To have an overview of the existing literature, } \\
\text { discussing the clinical relevance of this pathology, } \\
\text { its epidemiological characteristics, the available } \\
\text { psychometric scales, and the proposed treatment. }\end{array}$ & Literature review & $\begin{array}{l}\text { The link between the new technologies and their } \\
\text { psychopathological impact is not yet clear, and more } \\
\text { research is needed in this field. }\end{array}$ \\
\hline [17] & India & $\begin{array}{l}\text { To provide clarity on the social cognitive effects of } \\
\text { screen addiction, which leads to nomophobia } \\
\text { among teenagers, and to become better informed } \\
\text { as a researcher in order to inform others of best } \\
\text { practices and solutions with regard to new media } \\
\text { technology consumption }\end{array}$ & Literature review & $\begin{array}{l}\text { The level of addiction has an influence on the environment } \\
\text { with which the youth have connected. The level of } \\
\text { addiction stands high among hostel students in many cases. } \\
\text { Male and female respondents stand almost equal in many } \\
\text { research articles. The present study finds out whether the } \\
\text { teens are addicted to screen and smartphones or not and the } \\
\text { aspects which made them use the same platform. }\end{array}$ \\
\hline
\end{tabular}




\section{References}

1. Bartwal, J.; Nath, B. Evaluation of nomophobia among medical students using smartphone in north India. Med. J. Armed Forces India 2019. [CrossRef]

2. Prasad, M.; Patthi, B.; Singla, A.; Gupta, R.; Saha, S.; Kumar, J.K.; Malhi, R.; Pandita, V. Nomophobia: A cross-sectional study to assess mobile phone usage among dental students. J. Clin. Diagn. Res. 2017, 11, 34-39. [CrossRef]

3. Park, C.S.; Kaye, B.K. Smartphone and self-extension: Functionally, anthropomorphically, and ontologically extending self via the smartphone. Mob. Media Commun. 2019, 7, 215-231. [CrossRef]

4. Bragazzi, N.L.; Simona, T.; Zerbetto, R. The relationship between nomophobia and maladaptive coping styles in a sample of Italian young adults: Insights and implications from a cross-sectional study. JMIR Ment. Health 2019, 6, e123154. [CrossRef] [PubMed]

5. King, A.L.S.; Valença, A.M.; Nardi, A.E. Nomophobia: The mobile phone in panic disorder with agoraphobia: Reducing phobias or worsening of dependence? Cogn. Behav. Neurol. 2010, 23, 52-54. [CrossRef] [PubMed]

6. Kneidinger-Mueller, B. When the smartphone goes offline: A factorial survey of smartphone users' experiences of mobile unavailability. Comput. Hum. Behav. 2019, 98, 1-10. [CrossRef]

7. Lin, C.Y.; Griffiths, M.D.; Pakpour, A.H. Psychometric evaluation of Persian Nomophobia Questionnaire: Differential item functioning and measurement invariance across gender. J. Behav. Addict. 2018, 7, 100-108. [CrossRef]

8. Pivetta, E.; Harkin, L.; Billieux, J.M.; Kanjo, E.; Kuss, D.J. Problematic smartphone use: An empirically validated model. Comput. Hum. Behav. 2019, 100, 105-117. [CrossRef]

9. Basu, S.; Garg, S.; Singh, M.; Kohli, C. Addiction-like behavior associated with mobile phone usage among medical students in Delhi. Indian J. Psychol. Med. 2018, 40, 446-451. [CrossRef]

10. Aboujaoude, E. Problematic Internet use two decades later: Apps to wean us off apps. CNS Spectr. 2019, 24, 371-373. [CrossRef]

11. Tams, S.; Legoux, R.; Léger, P.M. Smartphone withdrawal creates stress: A moderated mediation model of nomophobia, social threat, and phone withdrawal context. Comput. Hum. Behav. 2018, 81, 1-9. [CrossRef]

12. Adawi, M.; Zerbetto, R.; Re, T.S.; Bisharat, B.; Mahamid, M.; Amital, H.; Del Puente, G.; Bragazzi, N.L. Psychometric properties of the brief symptom inventory in nomophobic subjects: Insights from preliminary confirmatory factor, exploratory factor, and clustering analyses in a sample of healthy italian volunteers. Psychol. Res. Behav. Manag. 2019, 12, 145-154. [CrossRef] [PubMed]

13. Lee, S.; Kim, M.W.; McDonough, I.M.; Mendoza, J.S.; Kim, M.S. The Effects of Cell Phone Use and Emotion-regulation Style on College Students' Learning. Appl. Cogn. Psychol. 2017, 31, 360-366. [CrossRef]

14. Adawi, M.; Bragazzi, N.L.; Argumosa-Villar, L.; Boada-Grau, J.; Vigil-Colet, A.; Yildirim, C.; Del Puente, F.; Watad, A. Translation and validation of the nomophobia questionnaire in the Italian language: Exploratory factor analysis. JMIR Mhealth Uhealth 2018, 6, 1-9. [CrossRef] [PubMed]

15. Mertkan, D.; Burcin, N.; Sezen-Gultekin, G.; Gemikonakli, O. Relationship between nomophobia and fear of missing out among Turkish university students. Cypriot J. Educ. Sci. 2018, 13, 549-561. [CrossRef]

16. Olivencia-Carrión, M.A.; Ferri-García, R.; Rueda, M.D.M.; Jiménez-Torres, M.G.; López-Torrecillas, F. Temperament and characteristics related to nomophobia. Psychiatry Res. 2018, 266, 5-10. [CrossRef]

17. Sandeep, T.K. A study on the effects of ICT enabled gadgets and screen addiction among mechanical engineering students. Int. J. Mech. Eng. Technol. 2018, 9, 1223-1227.

18. Ahmed, S.; Pokhrel, N.; Roy, S.; Samuel, A.J. Impact of nomophobia: A nondrug addiction among students of physiotherapy course using an online cross-sectional survey. Indian J. Psychiatry 2019, 61, 77-80.

19. Farooqui, I.A.; Pore, P.; Gothankar, J. Nomophobia: An emerging issue in medical institutions? J. Ment. Health 2018, 27, 438-441. [CrossRef]

20. King, A.L.S.; Valença, A.M.; Silva, A.C.O.; Baczynski, T.; Carvalho, M.R.; Nardi, A.E. Nomophobia: Dependency on virtual environments or social phobia? Comput. Hum. Behav. 2013, 29, 140-144. [CrossRef]

21. Santos, T.; Da Silva, L.K.; Abbas, W.; De Souza, L.A.; De Sá, L.V. Cade meu celular? Uma análise da nomofobia no ambiente organizacional. RAE Rev. Adm. Empresas 2017, 57, 634-635. 
22. Al-Balhan, E.M.; Khabbache, H.; Watfa, A.; Re, T.S.; Zerbetto, R.; Bragazzi, N.L. Psychometric evaluation of the Arabic version of the nomophobia questionnaire: Confirmatory and exploratory factor analysis-Implications from a pilot study in Kuwait among university students. Psychol. Res. Behav. Manag. 2018, 11, 471-482. [CrossRef] [PubMed]

23. Ali, A.; Muda, M.; Ridzuan, A.R.; Nuji, M.N.N.; Izzamuddin, M.H.M.; Latiff, D.I.A. The relationship between phone usage factors and nomophobia. Adv. Sci. Lett. 2017, 23, 7610-7613. [CrossRef]

24. Yildirim, C.; Correia, A.P. Exploring the dimensions of nomophobia: Development and validation of a self-reported questionnaire. Comput. Hum. Behav. 2015, 49, 130-137. [CrossRef]

25. Lee, S.; Kim, M.; Mendoza, J.S.; McDonough, I.M. Addicted to cellphones: Exploring the psychometric properties between the nomophobia questionnaire and obsessiveness in college students. Heliyon 2018, 4, 1-20. [CrossRef]

26. Ozdemir, B.; Cakir, O.; Hussain, I. Prevalence of Nomophobia among university students: A comparative study of Pakistani and Turkish undergraduate students. Eurasia J. Math. Sci. Technol. Ed. 2018, 14, 1519-1532. [CrossRef]

27. Gutiérrez-Puertas, L.; Márquez-Hernández, V.V.; Aguilera-Manrique, G. Adaptation and validation of the Spanish version of the nomophobia questionnaire in nursing studies. CIN Comput. Inform. Nurs. 2016, 34, 470-475. [CrossRef]

28. Ramos-Soler, I.; López-Sánchez, C.; Quiles-Soler, M.C. Adaptation and validation of the Yildirim \& Correia nomophobia scale in Spanish students of «compulsory secondary education». Health Addict. 2017, 17, 201-213.

29. Dasgupta, P.; Bhattacherjee, S.; Dasgupta, S.; Roy, J.K.; Mukherjee, A.; Biswas, R. Nomophobic behaviors among smartphone using medical and engineering students in two colleges of West Bengal. Indian J. Public Health 2017, 61, 199-204. [CrossRef]

30. Gutiérrez-Puertas, L.; Márquez-Hernández, V.V.; São-Romão-Preto, L.; Granados-Gámez, G.; Gutiérrez-Puertas, V.; Aguilera-Manrique, G. Comparative study of nomophobia among Spanish and Portuguese nursing students. Nurse Educ. Pract. 2019, 34, 79-84. [CrossRef]

31. Aguilera-Manrique, G.; Márquez-Hernández, V.V.; Alcaraz-Córdoba, T.; Granados-Gámez, G.; Gutiérrez-Puertas, V.; Gutiérrez-Puertas, L. The relationship between nomophobia and the distraction associated with smartphone use among nursing students in their clinical practicum. PLOS ONE 2018, 13, e0202953. [CrossRef] [PubMed]

32. Yildirim, C.; Sumuer, E.; Adnan, M.; Yildirim, S. A growing fear: Prevalence of nomophobia among Turkish college students. Inf. Dev. 2016, 32, 1322-1331. [CrossRef]

33. Darvishi, M.; Noori, M.; Nazer, M.R.; Sheikholeslami, S.; Karimi, E. Investigating different dimensions of nomophobia among medical students: A cross-sectional study. Open Access Maced. J. Med. Sci. 2019, 7, 573-578. [CrossRef] [PubMed]

34. González-Cabrera, J.; León-Mejía, A.; Pérez-Sancho, C.; Calvete, E. Adaptation of the Nomophobia Questionnaire (NMP-Q) to Spanish in a sample of adolescents. Actas Españolas Psiquiatr. 2017, 45, 137-144.

35. Argumosa-Villar, L.; Boada-Grau, J.; Vigil-Colet, A. Exploratory investigation of theoretical predictors of nomophobia using the Mobile Phone Involvement Questionnaire (MPIQ). J. Adolesc. 2017, 56, 127-135. [CrossRef]

36. Gentina, E.; Li-Ping, T.; Dancoine, P.F. Does Gen Z's emotional intelligence promote iCheating (cheating with iPhone) yet curb iCheating through reduced nomophobia? Comput. Educ. 2018, 126, 231-247. [CrossRef]

37. Ayar, D.; Özalp, G.; Özdemir, E.Z.; Bektaş, M. The Effect of Problematic Internet Use, Social Appearance Anxiety, and Social Media Use on Nursing Students' Nomophobia Levels. CIN Comput. Inform. Nurs. 2018, 36, 589-595. [CrossRef]

38. Betoncu, O.; Ozdamli, F. The disease of 21st century: Digital disease. TEM J. 2019, 8, 598-603. [CrossRef]

39. Arpaci, I.; Baloğlu, M.; Özteke, H.I.; Kesici, S. Individual differences in the relationship between attachment and nomophobia among college students: The mediating role of mindfulness. J. Med. Internet. Res. 2017, 19, e404. [CrossRef]

40. Rojas-Jara, C.; Henríquez, F.; Sanhueza, F.; Núñez, P.; Inostroza, E.; Solís, A.; Contreras, D. Adicción a Internet y uso de redes sociales en adolescentes: Una revisión. Rev. Española Drogodepend. 2018, 43, 39-54.

41. Rojas-Jara, C.; Ramos-Vera, J.; Pardo-González, E.; Henríquez-Caroca, F. Adicción a internet en adolescentes: Una breve revisión. Drugs Addict. Behav. 2018, 3, 267-281. [CrossRef] 
42. Ruiz-Palmero, J.; Sánchez-Rodríguez, J.; Trujillo-Torres, J.M. Utilización de Internet y dependencia a teléfonos móviles en adolescentes. Rev. Latinoam. Cienc. Soc. Niñez Y Juv. 2016, 14, 1357-1369. [CrossRef]

43. De la Villa Moral, M.; Suárez, C. Factores de riesgo en el uso problemático de Internet y del teléfono móvil en adolescentes españoles. Rev. Iberoam. Psicol. Salud 2016, 7, 69-78. [CrossRef]

44. Buiza-Aguado, C.; García-Calero, A.; Alonso-Cánovas, A.; Ortiz-Soto, P.; Guerrero-Díaz, M.; González-Molinier, M.; Hernández-Medrano, I. Los videojuegos: Una afición con implicaciones neuropsiquiátricas. Psicol. Educ. 2017, 23, 129-136. [CrossRef]

45. Guedes, E.; Sancassiani, F.; Carta, M.G.; Campos, C.; Machado, S.; Spear, A.L.; Nardi, A.E. Internet addiction and excessive social networks use: What about Facebook? Clin. Pract. Epidemiol. Ment. Health 2016, 12, 43-48. [CrossRef] [PubMed]

46. Okoye, C.A.; Obi-Nwosu, H.; Obikwelu, V.C. Nomophobia among undergraduate. Pract. Psychol. 2017, 7, 64-74.

47. Arpaci, I. Culture and nomophobia: The role of vertical versus horizontal collectivism in predicting nomophobia. Inf. Dev. 2019, 35, 96-106. [CrossRef]

48. Moher, D.; Liberati, A.; Tetzlaff, J.; Altman, D.G. Preferred reporting items for systematic reviews and meta-analyses: The PRISMA statement. Ann. Intern. Med. 2009, 151, 264-269. [CrossRef]

49. Aksnes, D.W.; Sivertsen, G. A Criteria-based Assessment of the Coverage of Scopus and Web of Science. J. Data Inf. Sci. 2019, 4, 1-21. [CrossRef]

50. Anshari, M.; Alas, Y.; Hardaker, G.; Jaidin, J.H.; Smith, M.; Ahad, A.D. Smartphone habit and behavior in Brunei: Personalization, gender, and generation gap. Comput. Hum. Behav. 2016, 64, 719-727. [CrossRef]

51. Correr, R.; Bijos, M.T. The use of cell phones by adolescents: Impacts on relationships. Adolesc. Saude 2017, 14, 24-39.

52. Csibi, S.; Griffiths, M.D.; Cook, B.; Demetrovics, Z.; Szabo, A. The Psychometric Properties of the Smartphone Application-Based Addiction Scale (SABAS). Int. J. Ment. Health Addict. 2018, 16, 393-403. [CrossRef] [PubMed]

53. Liu, T.; Sun, Y.; Li, Z.; Xin, T. The Impact of Aberrant Response on Reliability and Validity. Measurement 2019, 17, 133-142. [CrossRef]

54. Quicios, D.P.; Sevillano, M.L.; Ortega, I. Educational uses of mobile phones by university students in Spain. New Educ. Rev. 2013, 34, 151-163.

55. Siddiqi, N.; Jahan, F.; Moin, F.; Shehhi, F.A.L.; Balushi, F.A.L. Excessive use of mobile phones by medical students: Should precautions be taken? Biomed. Pharmacol. J. 2017, 10, 1631-1638. [CrossRef]

56. Tangmunkongvorakul, A.; Musumari, P.M.; Thongpibul, K.; Srithanaviboonchai, K.; Techasrivichien, T.; Suguimoto, S.P.; Non-Kihara, M.; Kihara, M. Association of excessive smartphone use with psychological well-being among university students in Chiang Mai, Thailand. PLoS ONE 2019, 14, e0210294. [CrossRef]

57. Throuvala, M.A.; Griffiths, M.D.; Rennoldson, M.; Kuss, D.J. Motivational processes and dysfunctional mechanisms of social media use among adolescents: A qualitative focus group study. Comput. Hum. Behav. 2019, 93, 164-175. [CrossRef]

58. Arpaci, I.; Baloğlu, M.; Kesici, Ş. A multi-group analysis of the effects of individual differences in mindfulness on nomophobia. Inf. Dev. 2019, 35, 333-341. [CrossRef]

59. King, A.L.S.; Martins, A.; Valença, A.M.; Cardoso, A.; Sancassiani, F.; Machado, S.; Egidio, A. «Nomophobia»: Impact of cell phone use interfering with symptoms and emotions of individuals with panic disorder compared with a control group. Clin. Pract. Epidemiol. Ment. Health 2014, 10, 28-35. [CrossRef]

60. Musa, R.; Saidon, J.; Rahman, S.A. Who's at risk for smartphone nomophobia and pathology; the young or matured urban millennials? Adv. Sci. Lett. 2017, 23, 7486-7489. [CrossRef]

61. Lee, Y.S.; Yang, H.S.; Jeong, C.J.; Yoo, Y.D.; Jeong, G.Y.; Moon, J.S.; Hong, S.W. Changes in the thickness of median nerves due to excessive use of smartphones. J. Phys. Ther. Sci. 2012, 24, 1259-1262. [CrossRef]

62. Mendoza, J.S.; Pody, B.C.; Lee, S.; Kim, M.; McDonough, I.M. The effect of cellphones on attention and learning: The influences of time, distraction, and nomophobia. Comput. Hum. Behav. 2018, 86, 52-60. [CrossRef]

63. Han, S.; Kim, K.J.; Kim, J.H. Understanding Nomophobia: Structural Equation Modeling and Semantic Network Analysis of Smartphone Separation Anxiety. Cyberpsychol. Behav. Soc. Netw. 2017, 20, 419-427. [CrossRef] [PubMed] 
64. Rosales-Huamani, J.A.; Guzman-Lopez, R.R.; Aroni-Vilca, E.E.; Matos-Avalos, C.R.; Castillo-Sequera, J.L. Determining symptomatic factors of nomophobia in peruvian students from the national university of engineering. Appl. Sci. 2019, 9, 1814. [CrossRef]

65. Bragazzi, N.L.; Del Puente, G. A proposal for including nomophobia in the new DSM-V. Psychol. Res. Behav. Manag. 2014, 7, 155-160. [CrossRef] 